\title{
The Inheritance of Modernisme: Antoni Fuster i Valldeperes
}

\author{
Magí Sunyer* (Facultat de Lletres, Universitat Rovira i Virgili) \\ magi.sunyer@urv.cat \\ http://orcid.0000-0003-1966-060X
}

\begin{abstract}
This article explores the characteristics of the literature of writers who, when literary Catalan modernism had died out, used many of the features of the movement in their work. An analysis of the costumbrism-based novel Perot i l'Estel (1932), by Antoni Fuster Valldeperes, shows the return to the debate on madness, the expression of individual standpoints and the portrayal of a wide range of revolutionary ideals, the main themes of which are Catalanism, universalism, Republicanism and anarchism.
\end{abstract}

Keywords: Catalan literature, madness, Republicanism, anarchism, costumbrism

\section{Introduction}

The third and fourth decades of the 20th century, just before the catastrophe, are one of the most interesting periods in both contemporary Catalan literature and the process of defining the identity of the country. In literature, the forces of the two previous decades faded: between 1906 and 1911, Modernisme was replaced by Noucentisme, which prevailed until 1923. Noucentisme was toppled not only by the second avant-garde - a generic term with many nuances, but which was much more clearly defined in Catalonia than the first avantgarde - but also by an outpouring of creativity of many different types and from many different sources. Writers of all ages took part. The age of Narcís Oller, Àngel Guimerà and Francesc Matheu was coming to an end: the leading figures died at this time and their institution of reference, the Floral Games, became part of linguistic "normality". Some of the old modernistes suddenly came back to life after a long period of struggling to come to terms with the new rules of Noucentisme.

The most obvious cases are Joan Puig i Ferreter and Prudenci Bertrana, who were once again enjoying the limelight and back to writing prolifically. Although Noucentisme had been affected as a movement by the collaboration of the Regionalist League with the dictatorship of Primo de Rivera, the works written at this time by Josep Carner and young writers at their peak such as Carles Soldevila were on a par with the very best in terms of their exceptional literary output. The avant-gardes made the change from futurism and cubism to surrealism. The young people from the generation of the Republic were just making themselves known as writers at this point, and they portrayed the numerous novelties of the society of the age, with no suspicion of the great setback that was about to be sprung upon them.

\footnotetext{
* Magí Sunyer is Professor of Catalan literature at the Universitat Rovira i Virgili. He has studied the works of 19th-and 20th-century Catalan writers, as well as the Catalan and Republican symbology in articles and books such as Els marginats
} 
Despite the diversity of this literary landscape, the writer this article is about does not really belong to any of these groups; he belongs to a group that is difficult to label because it lacks sufficient identity for it to be given a fully appropriate name. The first temptation, which on other occasions has been yielded to, is to call it "postModernisme". It is a highly graphic term to refer to the writers of the generation after the second Modernisme, who had been born in the 1890s and who largely continued in the same vein. However, perhaps we would do well not to use it, firstly, because of the term itself. "Modernisme" causes confusion if we do not limit ourselves strictly to Catalan cultural historiography. In the international arena, "modernism" is a quite different literary movement and too close in time for there to be no interference.

However, the international popularity of Catalan modernist architecture - particularly Gaudí - has helped to overcome this obstacle and to make "Catalan Modernisme" a well-known term in its own right. The same cannot be said of the term "post-Modernisme", which, generally speaking, is used to refer to a cultural trend that took place at the end of the 20th century", and art scholars such as Francesc Fontbona (1975) have even used it when speaking of some of the artists from the second generation of modernists, the one before Antoni Fuster Valldeperes.

The definitive argument is that these writers did construct a sufficiently original and different body of work for it to be unequivocally identified and to demand a cultural label all its own. The best writers are too unlike one another and they never thought that they belonged to the same group. In most cases, they probably never even felt close. Although they may have shared, or at least not rejected, some of the postulates or aesthetics of "Modernisme", these were all mixed up - to varying degrees - with "Noucentisme" and avant-garde influences. Perhaps the best way to refer to these writers is to say that they were "on the margin of Noucentisme" (Joan Fuster, 1982: 252).

This does not mean to say that - to name just two cases - that Josep Maria de Segarra was not "a case apart" (Joan Fuster, 1982: 217) or that Joan Salvat-Papasseit was post-Maragall, but there is no need to create generations or movements that do little to clarify things and just add further confusion. Even so, Modernisme had left an inheritance that was still active during the period of Noucentisme. The exclusive nature of Noucentisme meant that some writers, even those who were still young when the movement was at its peak, still identified with Modernisme. Noucentisme required absolute obedience from its devotees, which clashed with the freedom of spirit and independence championed by Modernisme.

This clash did not prevent some writers who had been brought up in the period in which the Regionalist League had been at its height and was the principal representative of Catalanism from joining up and taking active part at first. In most cases, they soon tired of it and drifted towards left-wing or Catalanist alternatives. This evolution must be taken into account if we are to understand the moment at which Noucentisme lost prestige, and new avenues were opened that the movement had felt really needed to be left unexplored. We shall explore all this in the particular case of Antoni Fuster i Valldeperes and his novel Perot i l'Estel, published in the year 1932.

\section{Preliminary outline}

There is no biography available on the painter, draftsman and writer Antoni Fuster i Valldeperes, and neither is there any major study, the latter requiring a research approach with a scope quite different from that of this article. While we wait for a full study, we can gather all the information that is available, which will shed some light on his career and his public life. The most valuable document on Fuster, the early literary portrait penned by Plàcid Vidal (1925), was published at such a time that it could only deal with Fuster as a young man, and this means that the most complete information about the writer is the one and a half columns written by Josep Olesti

socials en la literatura del Grup Modernista de Reus, Modernistes i contemporanis, Els mites nacionals catalans, La Ciutat Nova and Mites per a una nació. 
(1991: 296-297) in the Diccionari biogràfic de reusencs (Biographical Dictionary of People from Reus). The lack of bibliographical references means that we have to react with great caution to the more controversial aspects of the writer's life.

Josep Olesti provides us with the dates and places of his birth and death (Reus, 25 october 1895/Barcelona, 26 June 1942) and the names of his parents: Antoni Fuster Banús, painter - "artistic painter", he then clarifies - and Modesta Valldeperes Bartolí, both from Reus. His father's appearance in the second decade of the 20th century was described by Lluís Capdevila to Plàcid Vidal (1934: 375) - a man with long hair, a well-trimmed beard and a romantic look - and also in his memoirs:

He was rather a sullen man who had little to say for himself. He had quite a pronounced bald patch, wild, black hair, moustache and beard. He looked like an old soldier from the age of romanticism [...] transplanted to our heavenly age of peace and good food. (Capdevila, 1975: 277)

The young writer and painter had a tumultuous relationship with his family. Olesti mentions three admissions to the Pere Mata Institute (a mental health institution) in Reus, and Fuster Valldeperes himself dedicates a considerable number of pages to the issue in the novel we are going to examine. Plàcid Vidal (1925: 282) describes the young Fuster Valldeperes as "a fair boy, of quiet demeanour and admiring gaze." Plàcid Vidal's memoirs (1972: 86) suggest that in either 1922 or 1923, he spent some time away from Reus, and that by the end of 1923 or beginning of 1924, he had settled in Barcelona. In 1925, he married a girl from Reus (Vidal, 1972: 133). ${ }^{2}$ According to Olesti, however, it was in 1927 that he moved to Barcelona, where he opened a decorative arts shop on the Via Laietana, where he hosted painting exhibitions. ${ }^{3}$

If Fuster's journalistic work had been studied more closely, we would be better able to understand his ideological evolution; however, he comes across as a young man who was seduced by the political Catalanism of the second decade of the century (in 1919, he was the librarian for the board of the League's Nationalist Youth) (Navais, 2005: 54). We know that in October 1920, moved by the death of Terence MacSwiney, mayor of Cork, after a hunger strike in the process that led to the independence of Ireland, he took part in one wake organised by the Republican Nationalist Youth of Reus and in another organised by the Catalanist Youth of Borges Blanques (Navais, 2005: 130-131).

Perhaps his relationship with such displaced modernists as Joan Puig i Ferreter distanced him from conservative Catalanism. Black Gipsy, who in 1938 interviewed him for the journal Catalunya, explains that they were joined "by an old friendship made up of anonymous moments of struggle and persecution" (Black, 1938). He mentions various meetings at the Violeta de Clavé, a choral society with its headquarters in the old port area of Barcelona, which seem to have taken place towards the end of the dictatorship and which were attended by, among others, Maria Dolors Bargalló, Josep Maria Francès and Doctor Nicolau Battistini.

In 1930, he was a member, with Joan Puig i Ferreter, Carles Pi i Sunyer and Antoni M. Sbert, of the Organised Social Collective of Catalonia, which put forward collectivism as the solution for the economic problems of society (Black, 1938). In 1932, he worked at the Barcelona City Hall, in close relation to the mayor, Jaume Aiguader. ${ }^{4}$ There are indications to suggest that in 1934, he belonged to the Socialist Union of Catalonia, more specifically to Serra i Moret's social democratic sector (Caminal, 1984: 210), and in 1935, he was involved in a controversy about the role of intellectuals in the party (Caminal, 1984: 208-209). ${ }^{5}$

In the aforementioned interview, Black Gipsy remembers that Fuster's home was a centre of activity in the most repressive periods of the Republic and that they intended to create a revolutionary intellectual journal that was to

\footnotetext{
${ }^{1}$ At the end of the 20th century, the term "post-Modernisme" existed alongside "post-Modernity".

${ }^{2}$ In Plàcid Vidal's memoirs, the dates are difficult to specify exactly, but he seems to be referring to the year 1925 when he says that they got back from Majorca after their honeymoon.

${ }^{3}$ Plàcid Vidal (1972: 191) confirms that in 1927, "he set up a shop in Barcelona that was suitable for holding exhibitions, well located."

${ }^{4}$ Plàcid Vidal (1972: 287) explains that, on instructions of the mayor, he appointed him as a temporary municipal employee.

${ }^{5} \mathrm{He}$ wrote the article "Intellectuals and workers", in which he argued that the intellectuals had played a fundamental role in opening up the party to workers but that, once this had been done, the workers should take the lead.
} 
be called Mediterrània, which was going through the required administrative procedure on 19 July 1936. Among those who were to be involved were Miquel Serra Pàmies, Gabriel Alomar, Joan Puig i Ferreter, Andreu Nin and Diego Ruiz. In August 1936, his name was on the list of the members of the Group of Catalan Writers, affiliated to the Unión General de Trabajadores (UGT) (Campillo, 1994: 63) In 1937, he was the secretary to the Minister of Supplies of the Catalan Government, Miquel Serra i Pàmies (Anguera, 1977: 183). ${ }^{6}$

Between the first issue published on 14 January 1938 (Foguet, 1999: 19) and the eighth, during which time "he put his heart and soul into the tasks he was entrusted with by the Anti-Fascist Front" (Campillo 1994: 348), he directed the journal Meridià. Setmanari de literatura, art i política. Tribuna del front intel-lectual antifeixista, inspired by the Unified Socialist Party of Catalonia (PSUC). Fuster advocated a renewal of Catalan theatre so that it was in step with the political times, and he intervened in the controversy over the Ignasi Iglésias Prize of 1938, which had been declared void (Foguet, 1999: 112-113). It seems that he did not go into exile but remained in Barcelona, where he died 3 years after the war finished. Joaquim Santasusagna (2006: 339) mentions the moment that the Fascists forced entry into his home: "When they burst into his house in Valldoreix, they threw his papers all over the place."

\section{The writer: a modernista in a different age}

Initially, Fuster i Valldeperes' devoted his artistic endeavours to painting and drawing. Olesti (1991: 297) says that "he set up his workshop in Carrer de Barreres, 3" in Reus, that in 1918, he painted a flag for the Republican Youth of Riudoms and, in 1919, he won the first prize in the competition for the carnival poster. Also according to Olesti, he took his first steps in journalism, which was the start of his dedication to writing in 1913, when he started to write for Las Circunstancias and the Diario de Reus. In his city, he made regular, "almost daily" (Olesti, 1991: 297), contributions to Foment, with a regular feature entitled "Moments", for which he used the pseudonym Lluch, and other newspapers - Reus, Ciutat - and magazines such as La Veu del Camp (1918) - in which he also had a regular section - Revista del Centre de Lectura and the avant-garde La Columna de Foc.

Josep Olesti provides the following list of his publications: the dramas Camp perdut (Lost Countryside) (1915), La gran passió (The Great Passion) (1917), the monologue La bruixa (The Witch) (1918), L'heroina (The Heroine) (1918) and the unpublished Alba nova (New Dawn); the narratives La dama del retaule (The Lady of the Tableau) (1918), El príncep captiu (The Captive Prince) (1921), La balada del vell jardí (The Ballad of the Old Garden) (1922), L'ànima del vell castell (The Soul of the Old Castle) (1922), Devocionari de la novícia (The Novice's Prayer Book) (1922), L'eterna amada (The Eternal Beloved) (1922), El rodamon (The Wanderer) (1923), L'estudianta malaurada (The Unlucky Student) (1923), La dama del mirinyac blau (The Lady in the Blue Crinoline) (1923) and Perot i l'Estel (1934). In addition to this list, there are the collections of articles "Moments" and Evocacions (Evocations) (1921), the essay La politica a les comarques catalanes (Politics in the Catalan Counties) (1931) and two unpublished documents that may help to shed light on his biography and ideology: "Cartes a Eloi" ("Letters to Eloi"), his correspondence, and "Fins a mig camê" ("Up to Half Way"), his memoirs.

Antoni Fuster Valldeperes was one of those writers who were following in the wake of officially defunct Modernisme when he joined the world of culture. His initial devotion to the Modernist Group of Reus and his lasting friendship with its former members and his own circle in Reus and Barcelona make him a good example of those intellectuals who found a slightly more favourable environment in which to express themselves after Noucentisme had gone into decline in the second half of the 1920s, but very soon, they were sucked into the whirlpool of the Republic, the war and ultimate defeat. In Reus, despite collaborating with some of their journals, Fuster was not a member of the group of Josep Maria Prous i Vila, Joaquim Santasusagna and Josep

\footnotetext{
${ }^{6}$ In his capacity as secretary, he promised to take the necessary steps for the bomb damage caused to the Centre de Lectura to be repaired. Fuster used Ràdio Barcelona to raise awareness of the Centre's plight.
} 
Iglésies, and in the major controversies of the 1920s, Fuster held opinions that may not have directly contradicted Santasusagna but which were certainly different.

Plàcid Vidal recalls that in the second decade of the century, when he was twenty-something, Fuster belonged to a group of literature enthusiasts alongside Ricard Ballester, Josep Maria Pallejà, Josep Martorell i Òdena, Tomàs Martí i Torcal, Ferran Gay i Massó and Antoni Martí i Bages, who "revered the memory of Hortensi Güell", the painter who had committed suicide (Vidal, 1934: 334), organised events in remembrance of him and published the book Tribut en homenatge de l'artista Hortensi Güell [Tribute to the artist Hortensi Güell], in 1913. Lluís Capdevila (1975: 278) recollects their "obsession with the late Hortensi Güell" (Vidal, 1934: 375) and - with great irony - their characteristic anti-bourgeois attitude: "They looked down on - from some considerable height, it hardly needs to be said - all those who did not know who Baudelaire, Verlaine, Ibsen and D'Annunzio were" (Capdevila, 1975: 278).

This was the time when the group, and Fuster in particular, mythicised the memory of the Modernist Group of Reus and felt strong ties to those they believed represented it, especially Plàcid Vidal. Fuster held him in great awe and asked his advice - even though he did not take much notice of what he said - about the first play that he wrote, Camp perdut (Lost Countryside), which was first performed at the end of 1915 and published - with a drawing by Fuster on the cover - the following year (Vidal, 1934: 374-375). The whole group took part in the tribute to Antoni Isern in Alcover in 1916 (Vidal, 1934: 383; Cavallé, 1983: 3-14), and the only reason Fuster did not attend the festivities in honour of Josep Aladern in 1919, also in Alcover, was that he was spending some time in Breda because of ill health (Vidal, 1934: 439). He managed to get his novel The Lady of the Tableau (1918) published in the series "La Novel-la Nova" due to the influence of Plàcid Vidal (Vidal, 1934: 441).

In June 1918, he was runner-up in the literary prize organised by the Agrupació Horaci for his play The Heroine (Navais, 2005: 36). In August 1920, he helped organise a meal at the Remei Hermitage in Alcover in honour of Plàcid Vidal for the publication of the first series of Els singulars anecdotics (Extraordinary and Peculiar Characters) (Navais, 2005: 68) - Fuster's face appeared on the extended second edition in 1925. On 9 October of the same year, there was a public reading - set up by Plàcid Vidal - of "Moments", a collection of articles that his friends wanted to have published by Nostra Parla (Our Language), from Barcelona (Navais, 2005: 75), which was attended by Alfons Maseras, Plàcid Vidal, Josep Maria Prous i Vila and the painter Joaquim Biosca, who had a celebratory meal the next day in his studio. In the same year, the reading was also held at the Centre de Lectura (Reading Centre) in Reus.

When Plàcid Vidal first arrived in Reus, the two men became friends at once although the relationship soon cooled off. ${ }^{7}$ Fuster became closer to the painter Joaquim Biosca and the group of old modernists who had collected around the Vidal brothers - Alfons Maseras, Cristòfor de Domènech and Joan Puig i Ferreter - who were the first people he got on with when he moved to Barcelona. One example of his friendship with Alfons Maseras is depicted by the two articles he dedicated to him in the magazines Alfar and Prisma (Corretger, 1995: 130). ${ }^{8}$ He was such a close friend of Joaquim Biosca that he took care of him on his deathbed and he improvised the dying painter's marriage to his mistress (Vidal, 1972: 292-293).

A leading figure in the cultural life of Reus of the second and third decades of the 20th century, in November 1925, Fuster got involved in the controversy initiated by Antoni Martí i Bages on the continuation of the Revista del Centre de Lectura (the Reading Centre Magazine) by publishing an article entitled "The Magazine We Can Make" in the newspaper Reus (Anguera, 2005: 218). And in March 1926, he added fuel to the flames of another controversy with some comments in Les Circumstàncies about Joaquim Santasusagna's article "Our Great Local Topic" (Anguera, 1977: 191). The literary career of Antoni Fuster i Valldeperes in Reus and Barcelona shows him to be what we have mentioned earlier: a member of the generation after Modernisme who did not feel

\footnotetext{
${ }^{7}$ Vidal (1972: 31) mentions a clash after which they drifted apart. They stayed apart for some time largely because of Vidal's suspicions.

${ }^{8}$ The articles are "Alfonso Maseras", in Prisma. Revista Internacional de Poesía, Paris-Barcelona, vol. II, no. 4, August 1922, pp. 220-223, and "El poeta Alfonso Maseras”, in Alfar, La Corunya, no. 36, January 1924, pp. 12-13.
} 
comfortable with Noucentisme and who moved in marginal circles in the orbit of the former modernists from the Reus group.

\section{The novel}

It has already been mentioned that a painstaking study of all the articles that Antoni Fuster i Valldeperes published would provide a clearer outline of his evolution as a writer but, until this has been done, the examination and interpretation of his longest novel, published at his peak, reveal features that show his connection with Modernisme, but which were projected, with new ingredients, to the moment at which the book was published.

Perot i l'Estel is a singular novel that can create a certain feeling of confusion. Joaquim Santasusagna (1934) expressed this confusion in a criticism of what he considered to be the novel's two basic defects: the fact that it is made up of a series of discrete sections and its excess volume, which "dilutes the interest of the anecdote." With his Noucentista mindset, Santasusagna rejoices that the style had restricted the pomp of excessive use of adjectives but criticised the "bombastic length of the sentences." On the other hand, the critic writing for Clarisme, who signed "Aspirant" (1934), pointed out the virtues of a style that was "today a recommended model: sober, straightforward, correct, clear." This difference in criteria may reveal an aesthetic change. In the novel, various plots converge and long scenes are interspersed in which the action either comes to a standstill or digresses from the central narrative. This article focuses on two of these "digressions". But, before we start, let us briefly describe the novel.

In an introductory note, the narrator says that the novel is the re-creation of one of the folktales that he was told as a young boy by a cooper. "It really impressed me because it showed the brightness of our region and the features of our psychology at the turn of the century" (Fuster, 1934: 9). The novel was published in such a way that it seemed that it was the first of a series with the general title of "The Old Cooper's Folktales". However, as it turned out, it was the only one. The novel portrayed scenes of daily life from the city of Reus at the end of the 19 th and the beginning of the 20th centuries, even though the chronology was not absolutely accurate in some respects. Fuster attributed this, and the colloquial language, to the cooper's disordered exposition:

He would brighten up his narratives with little tastes of popular comedy and invigorate them with epic touches, which, inspired by the ideals he shared with the most daring of the $1800 \mathrm{~s}$, he made much of, highlighting them with anachronisms and common local expressions, much criticized by the demanding analysts and purists, the former obsessed with the dryness of accuracy and the latter with the integrity of the language. I, however, take little notice of such issues for I feel that they give situations greater flexibility, the atmosphere more colour and the characters of his tales sharper definition. (Fuster, 1934: 9)

Indeed, we realise that although the story of Anselm, who represents the author, and his conflicts with his family, narrated in the past tense, must have taken place towards the end of the second decade or the beginning of the third, during the lunch scene in Salou, the ban on dancing sardanes in 1908 is mentioned as if it were a recent event: "You say you are so liberal but in the middle of Plaça Prim you brutally put a stop to the exhibition of sardanes, the sacred dance of the Catalans" (Fuster 1934: 258). The time frame is fictional and bears little relation to any real period even though the reference to historical events creates this illusion. Likewise, also during the scene in which they have lunch on the beach, the characters mention that a lunatic asylum is soon going to be built in Reus and that it is going to be a "lucrative business" (Fuster, 1934: 255). The reference is clearly to the Pere Mata Institute even though it had been opened in 1897 and Fuster had been a patient there in the second decade of the century. Anselm, on the other hand, had been definitively discharged many years before.

By saying that the origin of the novel lay in the stories told by a craftsman and insisting not on the coherence and the appropriateness of language but on local colour, Fuster reveals his costumbrist approach. Of the 
criticisms published about the novel, this was the feature that was most highlighted. In La Humanitat (Humanity), Agustí Esclasans pointed out the "skilful hand of the painter of customs", defined it as "an entr'acte in novel form" and compared Fuster with Rabelais. He even stated that the narrative shows that the customs novel is by no means dead and, in clear disagreement with Santasusagna, felt that it could have been twice as long. The narrative thread of the novel hangs on the affection that Perot, a cart driver, has for Estel, a horse that is born on the first page of the novel and dies at the end. Symbolically, Estel is the last representative of the heroic age, and her death sees this world go into terminal decline. The last sentence of the book destroys the aureole of memories with the evidence of the present: "As I crossed the street, I was brought to my senses by the loud blast of a car's horn" (Fuster, 1934: 348).

The description of characters or scenes takes precedence over narrative action. This explains the two points at which the action is brought to a halt by the two great portrayals of customs: the traditions of Good Friday (particularly the procession) and the picnic on the Capellans beach in Salou to celebrate the Assumption. I do not intend to go into any great detail about this. I shall merely gloss over some of these costumbrist features: Perot is an archetypal character - a gypsy-like cart driver who loves animals, has no real notion of the concept of authority, is used to leading a free life, and, like a good federalist, is anti-clerical; the novel portrays local Reus scenes - the squares, the markets and fairs, the taverns, the cafés, the inns, the card games - and describes local festivals; the characters are referred to by their nicknames rather than their names; and gypsies play a leading role.

The fact that it is a novel in code is revealed by a copy found in the Centre de Lectura in Reus that had belonged to the writer Josep Iglésies. It contains a page that lists many of the characters and the real people they represent, most of whom were well known in the city. The story is not only autobiographical in nature because of the importance given to the character of Anselm, the author's literary alter ego; it is also Fuster's explicit revenge for the way he was treated by his family and at the mental institution, where he had been admitted for treatment.

Although the settling of scores with the past, the little effort spent in trying to disguise what is essentially an autobiography and the ease with which real people can be seen to be represented by characters with fictitious names all mean that the novel resembles those written by old modernists who had come back into fashion in those years (for example, Prudenci Bertrana and, in particular, Joan Puig i Ferreter, who was among Fuster's acquaintances in Barcelona), of much greater interest is the way in which he deals with madness and the advancement of progressive ideas (two features that are extremely typical of Catalan modernist literature).

\section{Madness, Catalanism and revolution}

The novel has many features that have their origin in Modernisme. The importance given to gypsies, the socalled "damned race" (Fuster, 1934: 318) - Perot himself has gypsy blood flowing through his veins - not only gives a touch of colour and exoticism but also recalls the literature by Juli Vallmitjana and the paintings by Isidre Nonell, who is surely that "phenomenal painter who is said to paint gypsies as authentic as the ones who live in Munta i Baixa" (Fuster, 1934: 168). Gypsies are associated with adventure. One of their chiefs makes a connection with Excelsior by Joan Maragall: "Happy are the people who even in their splendour feel the burning desire (as was said by a leading poet of your race, often looked down on by cretins) to discover new horizons!" (Fuster, 1934: 319). Of all these features, I would like to focus on two.

\subsection{A madman or a genius?}

The debate on madness came to the fore in Catalan literature in the 1890s "in the context of the crisis of positivism and in the frame of "the Verdaguer case"" (Dasca, 2015: 32), when the theories of Eduard von Hartmann, Arthur Schopenhauer, Friedrich Nietzsche, Cesare Lombroso and Max Nordau all converged. It was in this period that literature "constructs the modern images of the madman and takes part in the debate on the 
limits of madness" (Dasca, 2015: 33). Narratives by Narcís Oller, Marià Vayreda, Víctor Català, Joaquim Ruyra and Diego Ruiz, poems by Miquel Costa i Llobera, plays such as El geni and El boig, by Frederic Pujulà and Emili Tintorer, all have madness at the centre of the action. It is the line between genius and madness that is most directly involved with the condition of being an artist, most directly interests the cultural movements that sprang out of Romanticism, and it is this line that attracted most attention. ${ }^{9}$ In the particular case of Reus and the Pere Mata Institute, we should not lose sight of the fact that, at different times, two artists of the stature of Joaquim Mir and Juli Vallmitjana had been admitted. In Perot i l'Estel, the subject took on an extra dimension as a result of Fuster's personal circumstances at the time. In his biographical note about Antoni Fuster Valldeperes, Josep Olesti (199: 297) writes the following:

Because of mental illness or his excessive fondness for drinking, his father felt obliged to have him admitted to the Pere Mata Institute in Reus. Once he had been declared fit, he returned to the family home but in 1914 he was re-admitted at his own request and, in 1922, he underwent a third and final treatment in the same institution.

Olesti does not say where he got his information from but he does make quite definite statements - "he felt obliged to have him admitted", "at his own request" - about highly delicate aspects. We have already seen that Plàcid Vidal, who makes no reference to Fuster's being admitted to a psychiatric institution, mentions that he had gone to Breda for health reasons (Vidal, 1934: 439).

Antoni Fuster i Valldeperes uses Perot $i$ l'Estel to explain his version of events in an aside. Among the spectators at the Easter procession, a washerwoman speaks of how unfairly a young craftsman and brilliant writer called Anselm had been treated by his relatives - with the fictional names of Unça, Secall and Contrabaix - who had had him taken away to the Agulla lunatic asylum for reasons of their own. Against a background of comments from others who are watching the procession, the washerwoman explains that Anselm had been admitted so that he could get out of doing the military service and that afterwards his uncle - Contrabaix - had had him locked away again. Even in the passage about the lunch in Salou, after Anselm's speech, the plotters go back to the idea of having him interned in the lunatic asylum.

According to the washerwoman, his relatives had various reasons for making it seem that he was mad: in the family, particularly among the women, there had been cases of alcoholism and now he was having to pay the price; after his mother's death, his father - whose nickname was Bessó - wanted to marry a niece of his, but she rejected him because she preferred Anselm, who took no notice of her; Anselm's father, a painter of both walls and pictures - like his son - was jealous of Anselm because he played an important role in the artistic movement of the city, and when he wanted to exhibit his paintings at the Centre, he made him leave town or sent him back to the asylum; the family did not want Anselm to write in the newspapers or perform his plays because he used Catalan; his uncles wanted everybody to think that he was mad so that they could keep Bessó's money and properties for themselves.

What is more, in one of his plays that had won a prize at the Floral Games of the Working Man's Science and Arts Association, Anselm had explained the ordeals that the patients in the lunatic asylum were subject to and had denounced the irregularities in the decision to have him admitted: "No judge, attorney, mayor, doctor or any living animal saw him to check that he was mad. The papers were signed without so much as a by your leave" (Fuster, 1934: 159). In response to a new family threat to have him admitted, Anselm had written an article in which he said that he would explain it all in a book. After he was locked up again, he was released owing to the intervention of a working class leader, one of the brothers of his mother- a great Catalanist - and a painter who, from the information available, seems to be Nonell.

In stark contrast to the discredit of his constant admissions to the lunatic asylum, the washerwoman describes Anselm as "such a smart lad that he wrote in all the fashionable newspapers, could paint a lovely picture as quick as a flash and was very handy at mixing the paints in their pots" (Fuster, 1934: 141). These words do not seem to refer to the genius of an artist who was head and shoulders above his contemporaries, but we should not

\footnotetext{
${ }^{9}$ Charles Baudelaire's "Albatross" had a considerable influence on Catalan literature at the turn of the century and, since then, as a metaphor of the condition of the artist in society.
} 
be deceived by the colloquial language that she uses to talk about a subject who is often intellectualised. Neither should we lose sight of the fact that we are dealing with a "popular novel" in which matters of a more elevated tone are expressed simply and more light-heartedly. Without any substantial change in register, another character explains that the reaction of people to those who are different and, more specifically, to the artist, however select and refined s/he may be, is lack of understanding, mockery and marginalisation.

The reason for this, according to a whitewasher who intervenes in the conversation, is jealousy: "All men who stand out from the rank and file of their class, if their family and acquaintances are dunces, are regarded as mad or haunted" (Fuster, 1934: 148). It is not difficult to connect this idea to the texts produced by the members of the Modernist Group of Reus - Joan Puig i Ferreter, Hortensi Güell - in which a poet who is working in the dead of night to achieve that sublime work that will establish him as one of the greats and redeem the people falls foul of night-time revellers who throw stones at his window because they think he is useless and lazy. There is also a clear connection with one of Puig's best novels Els tres al-lucinats [The Dumbfounded Three].

The influence of the modernist conception of madness on Fuster's novel is clear, but it does not explain it fully. He also incorporates part of the approach adopted in the literature of the 1920s and 1930s, which is described by Maria Dasca (2008: 110) in the following terms: "He portrays moral conflicts, which focus, on the one hand, on the conflict of the self; and, on the other, on the link between the self and society (the family environment, the possibilities of a workers' revolution and the admission to the lunatic asylum). We have just seen that the use of autobiographical elements, the "family as a sign of disorder" (Dasca, 2008: 114) and the denouncement of malpractice in the asylum are all features essential to the topic of madness in the novel. However, the more avant-garde assumptions about madness have no effect: it does give rise to substantial literary experimentation such as the internal monologue, writing nonsense or verbal excesses. In fact, the opposite is true: as we have pointed out earlier, the language of Perot i l'Estel is colloquial.

The grand finale reserved for the hero, the genius, in the speech Anselm makes during the lunch in Salou gives us the chance to see the extent to which the accusations of madness were unfounded. If anything, they had been mistaken for originality, with a sort of genius.

\subsection{Catalanism, individualism and revolution}

In the Catalan literature of the third and fourth decades of the 20th century, there are few ideological novels or novels that deal with recent, contemporary social conflicts, but they are more common than in the age of Noucentisme, when they were systematically avoided. Fuster's novel is one of the least known because it is not given much space - if any - in the histories of Catalan literature and because, when it is spoken of, the focus is on its costumbrist features. However, it is a clear example of literature written "with the rhythm of blood", which is the link Modernisme established between life and literature, and which found "a proper route of expression through the literature of the self, motivated by retrospective stimuli that bring the theme of anarchy up to date from a universal perspective" (Dasca, 2007: 411). But we never find out whether Fuster, or his character, ever actually got to be a militant anarchist.

Anselm introduces himself in person in the novel on the pretext of a horse race (which Estel wins) on which there is a lunch in Salou at stake. At this time, he is living in Barcelona where he has gained a prestige that he shows he deserves on this occasion. The long interlude provides the most detailed information about Anselm's ideas - and, we suspect, Fuster's - than anywhere else in the novel.

This passage contrasts two ideological options that are struggling for supremacy among the local people. The first, which is present throughout, is the old Republicanism, federal or possibilist. Perot is a federalist; his main reference is Francesc Pi i Maragall; Castelar is his model of eloquence. However, the passage on the Easter procession denounces the hypocrisy of the Republican leaders, who stir up anti-clerical feeling among the people and then take part in the Good Friday procession: "He says he is such a republican and off he goes to parade in the procession. Mother of God, what a fraud!" (Fuster, 1934: 138). Changes in attitude when people improve their social position also come in for criticism. For example, when Contrabaix's wife is well off, she hardly moves from the church and when "she used to operate the spinning frame at the Vapor Vell textile factory 
she used to swear more than Perot and she would have razed all the convents to the ground and roasted all the nuns and monks on an open fire" (Fuster, 1934: 139).

The anecdotal nature of this passage, largely due to the vulgar tone of the washerwoman, changes completely in the lunch scene in Salou. The rhetorical speech given by Conillera, a possibilist, contrasts with the speech given by Anselm. The presence of the young man intimidates the old Republican and forces him, despite his initial intentions, to speak in Catalan. The commonplace speech, full of all the clichés of old Republicanism Citizenship; Liberty, Equality and Fraternity; the Republican rooster; the liberal and Republican mythology of Reus; anti-clericalism - culminates in the rhetorical announcement of the immediate advent of the Republic.

At the beginning of his intervention, Anselm makes it clear where he stands and identifies the differences between the possibilist and himself as a generational issue: "I cannot see the world as Conillera sees it, because I have just arrived and he is about to leave" (Fuster, 1934: 262). Indeed, in Anselm's speech, the Republicanism of the 1800 s makes way for the symbols of a new space that we recognise as that of the left-wing, libertarian Catalanism of the turn of the century and subsequent decades. In the scene set at the Easter procession, a justification had already been given for Anselm having a pistol "because in those times all men of progressive ideas had to have one if they wanted to be safe" (Fuster, 1934: 165). Although the action is supposedly set at the beginning of the century, this sentence refers to 2 decades afterwards, to pistolerisme (the age of gunmen), "when men were shot down in the middle of the street." This is confirmed when mention is made of one of Anselm's friends, a working man and painter, "whose name made the rich quake in their boots" (Fuster, 1934: 165). Just in case there were any doubts about this transparent reference to Salvador Seguí, the Noi del Sucre (Sugar Boy), they are immediately removed by the clarification that "he had a very sweet name" and that "a few days later, that heroic worker died in the street in Barcelona, gunned down by the bourgeoisie" (Fuster, 1934: 166).

Anselm's speech could have been the product of the most extreme social theatre dramatists of the first decade of the century. He reveals himself to be a radical Catalanist, perhaps even in favour of independence: "A few years ago many Catalans, myself included, realized that our country is enslaved and we are doing all we can to free ourselves" (Fuster, 1934: 264). In his justification of the anarchist bombings, with an argument that has Ibsenian overtones, he does not renounce direct action: "The enemies of today's society are the friends of tomorrow's" (Fuster, 1934: 264). He declares himself to be anti-localist - in a novel that stands out for its local colour - and a universalist: "Just as [...] the statues of historical heroes will be smashed to smithereens, the walls between nations and the walls between races and estates will also come tumbling down" (Fuster, 1934: 267).

In keeping with the individualism of modernist literature and the debate on the individual and the masses, which was the basis of texts such as Les multituds, by Raimon Casellas, and Elogi del poble, by Joan Maragall, he railed against what had recently been referred to as the "old politics": "We shall also get rid of those leaders of masses, truly herds of sheep the backs of whom they use to clamber upwards towards all that they have lusted after. [...] These are politicians" (Fuster, 1934: 268). He does not spare his listeners' feelings; rather he explains that these professionals of deception exist because of the shortcomings of the people: "We must accept that the people, the masses, have still not come of age. [...] The more ignorant men are, the more impressed they are by other men" (Fuster, 1934: 269). The solution lies in educating the people:

After they have put their backs into their reading, the day will come that the peasants and the workers will realise that the political route is by no means the shortest and it does not match their aspirations. Political revolutions end up with a change of guests at the table of the host. (Fuster, 1934: 271)

This awareness will give rise to the driving force that will lead to the desired society: "Thus, little by little, at a snail's pace if necessary, we shall take no heed of those trying to sell us outdated doctrines and move towards the new age in which all men will be brothers, who with fraternal love will share the fruit that hangs from the branches and work together to reach up to them" (Fuster, 1934: 276). Individualism and heroism will be the very basis of the revolution, which will be successful because of lone wolves, “"men of brightness' [...] who 'will create the pillar of fiery logic which will destroy the ill-fated tradition [...] that we have been unable to do away with because the sabre and the whip still prevail"' (Fuster, 1934: 276). At the end of Anselm's speech, the possibilist Conillera exclaims bitterly, "You're quite the anarchist, aren't you!" And Anselm responds, “Or 
Christian!" (Fuster, 1934: 277). Let us not forget that Christ was an anarchist myth, in opposition to the Church and the clergy (Litvak, 1981: 41-42).

\subsection{Conclusion}

We have already mentioned that the text we are dealing with is quite an extraordinary one: it is written in the costumbrist and localist tradition; it is the means by which he carries out personal vengeance; it is largely autobiographical; it is a novel in code; and in two breaks in the narrative, he makes his modernist referents explicit, although they have evolved over the course of time and have acquired new significance in the Catalonia of the 1920 s and 1930 s.

The text does not always transmit ideological clarity, but this perhaps gives us valuable information about the convergence of ideas in the writers from this age, which did not necessarily lead to specific political options and each case was determined by their own personal experiences. Perhaps, we need to understand that the fact that Antoni Fuster Valldeperes, who evolved from the Nationalist Youth Party to the Socialist Union, expresses his ideas through Anselm - a radical nationalist and internationalist, individualist, allegedly an anarchist - does not mean that the doctrine of the parties to which we know he belonged necessarily coincides with these principles.

Acknowledgements. This study is part of the research carried out by the Universitat Rovira i Virgili's group National and Gender Identity in Catalan Literature, from the research group Identities in Catalan Literature (GRILC), (SGR 2014 - 755).

\section{References}

Anguera, P.: El Centre de Lectura de Reus: una institució ciutadana. Barcelona: Edicions 62, 1977.

Anguera, P.: De les lletres i les arts. Reus: Associació d’Estudis Reusencs, 2005.

Aspirant. “Perot i l'Estel, d’Antoni Fuster Valldeperes”, Clarisme, no. 35 (16 June) (1934): 2.

Black Gipsy "Front intel-lectual antifeixista. Dialogant amb l'amic Fuster i Valldeperes, director de Meridià", Catalunya, no. 278 (12 January) (1938): 4.

Caminal, M.: Joan Comorera. Catalanisme i socialisme. Barcelona: Empúries, 1984

Campillo, M.: Escriptors catalans $i$ compromís antifeixista (1936-1939). Curial Edicions Catalanes/Publicacions de l'Abadia de Montserrat, 1994.

Capdevila, L1.: De la Rambla a la presó. Barcelona: Paraula Viva, 1975.

Cavallé i Busquets, J.: “L'Isern, record i oblit”, Butlletí del Centre d'Estudis Alcoverencs, 22, (April-June) (1983): 6-14.

Corretger, M.: Alfons Maseras: intel-lectual d'acció i literat. Curial Edicions Catalanes/Publicacions de l'Abadia de Montserrat, 1995.

Dasca, M.: “'Una ficció trepidant i dramàtica'. Notes sobre la representació de l'anarquista en la prosa dels anys 20 i 30". In: La projecció social de l'escriptor en la literatura catalana contemporània, edited by Ramon Panyella. Punctum \& GELCC, 2007, pp. 403-411.

Dasca, M.: "Bogeria i sentit en la narrativa catalana contemporània", Revista de Catalunya, 245 (December), (2008): 97-118. 
Dasca, M.: “'Coses que fan so d'esquerdat'. La bogeria i la narrativa catalana contemporània”, L'Avenç, 410 (March) (2015): 32-37.

Esclasans, A.: “Converses literàries. Perot i l’Estel”, La Humanitat (13 June) (1934): 4.

Foguet i Boreu, F.: El teatre català en temps de guerra i revolució (1936-1939). A propòsit de Mirador $i$ Meridià. Institut del Teatre/Publicacions de l'Abadia de Montserrat, 1999.

Foment. Setmanari Nacionalista Republicà (25 May and 17 June), 1934.

Fontbona, F.: La crisi del Modernisme artístic. Barcelona: Curial edicions catalanes, 1975.

Fuster, J.: Literatura catalana contemporània. Barcelona: Curial edicions catalanes, 1982.

Fuster Valldeperes, A.: Perot i l’Estel. Barcelona: Llibreria Catalònia, 1934.

Litvak, L.: Musa libertaria. Barcelona: Antoni Bosch, editor, 1981.

Navais i Icart, J.: Josep Maria Prous i Vila. Poemes d'amor i de guerra. Volum I: 1899-1931. Reus: Edicions del Centre de Lectura, 2005.

Olesti, J.: Diccionari biogràfic de reusencs, vol. 1. Reus: Ajuntament de Reus, 1991.

Santasusagna, J.: [pseud. Jeroni Prat] "Perot i l'Estel, per Antoni Fuster i Valldeperes", Les Circumstàncies. Portaveu d'Acció Catalana, 131 (6 June) (1934): 1.

Santasusagna, J.: "Pròleg no publicat al llibre de Pere Anguera Bibliografia catalana reusenca", in Xavier Ferré $\mathrm{i}$ Trill. Nació i excursionisme. Biografia intel-lectual de Joaquim Santasusagna. Reus: Associació d'Estudis Reusencs, 2006.

Vidal, P.: “Antoni Fuster Valldeperes”. In: Els singulars anecdòtics. Editats per segona vegada i seguits d'una nova sèrie. Barcelona: Joaquim Horta, 1925.

Vidal, P.: L'assaig de la vida. Barcelona: Edicions Estel, 1934.

Vidal, P.: El convencionalisme de la vida. Barcelona: Fundació Salvador Vives Casajuana, 1972. 